\title{
UPAYA PENCEGAHAN KEGAWATAN JANTUNG DAN NEUROLOGIS PADA KADER KESEHATAN DI DESA SUMBERBENING KECAMATAN BANTUR KABUPATEN MALANG
}

\author{
Nadia Oktiffany Putri ${ }^{1}$, Dyah Untari ${ }^{2}$ \\ ${ }^{1,2}$ Prodi S1-Keperawatan, STIKes Panti Waluya Malang \\ Jalan Yulius Usman No.62, Malang 65117, telepon: 0341-369003 \\ e-mail: nadiaoktiffany@yahoo.com
}

\begin{abstract}
ABSTRAK
Kondisi kegawatan jantung seperti serangan jantung dan neurologis seperti serangan stroke merupakan salah satu penyebab kematian tertinggi di dunia. Salah satu karakteristik yang ditemukan di Desa Sumberbening, yang merupakan lokasi kegiatan kemitraan masyarakat, adalah masih banyak penduduk yang merupakan kategori penduduk hampir miskin dan miskin. Keadaan ekonomi yang rendah menjadi salah satu indikator dalam rendahnya pengetahuan masyarakat, termasuk pengetahuan mengenai kegawatan jantung dan neurologis. Permasalahan tersebut menjadi salah satu dasar pelaksanaan program kemitraan masyarakat dengan tujuan untuk memberikan pengenalan mengenai faktor risiko dan penyakit - penyakit yang berpotensi menimbulkan kondisi kegawatan jantung dan neurologis. Upaya pencegahan yang dilakukan ialah melalui pemberian pendidikan kesehatan dan pelatihan dalam melakukan deteksi dini kondisi kegawatan jantung dan neurologis dengan peserta kegiatan ialah kader kesehatan dan kelompok Pembinaan Kesejahteraan Keluarga (PKK). Selama proses kegiatan, jumlah peserta yang hadir telah melebihi $50 \%$ dari target yang diharapkan. Kegiatan yang dilakukan telah menjawab permasalahan yang ada di Desa Sumberbening, yaitu menambah pemahaman dan kewaspadaan masyarakat mengenai kondisi kegawatan jantung dan neurologis. Adapun target jangka panjang dari kegiatan ini ialah para kader kesehatan dan kelompok PKK untuk selanjutnya dapat membagikan informasi dan keterampilan yang telah dimiliki kepada seluruh masyarakat di Desa Sumberbening.
\end{abstract}

Kata Kunci: deteksi dini, kader kesehatan, kegawatan jantung, kegawatan neurologis

\section{ABSTRACT}

Cardiac and neurological emergency such as heart attack and stroke attack are one of the highest causes of death in the world. One of the characteristics in Sumberbening Village, which is the location of the community partnership activity, is that there are still many people who are living in poverty. Lower socioeconomic status is one of indicators that someone is in the low level of public knowledge, including knowledge about cardiac and neurological emergencies. This problem has become one of the bases for implementing community partnership programs with the aim to provide an introduction to risk factors and diseases that potentially causing cardiac and neurological emergency conditions. Prevention efforts are delivered through the provision of health education and training in early detection of cardiac and neurological emergency conditions. The participants in this activity are the community health groups. During the activity process, the number of participants are more than 50\% of the expected target. This activity has answered the existing problems in the Sumberbening Village, which is to increase public understanding and alertness regarding cardiac and neurological emergency conditions. The long-term target of this activity is preparing the community health group to further be able to share information and skills that they have to all the people in Sumberbening Village.

Key Words: early detection, community health group, cardiac emergencies, neurological emergencies 


\section{PENDAHULUAN}

Desa Sumberbening merupakan salah satu desa yang terletak di wilayah Malang Selatan yang berada di Kecamatan Bantur Kabupaten Malang, terletak antara $112^{\circ} 30^{\prime} 00^{\prime}$ " Bujur Timur$112^{\circ} 34^{\prime} 00,00$ " Bujur Timur dan antara 8'18'00" Lintang Selatan - 8'25'00" Lintang Selatan. Desa Sumberbening memiliki jumlah penduduk sebanyak 5834 jiwa yang terdiri dari 1682 Kepala Keluarga (KK) dengan jumlah rumah tangga hampir miskin sebanyak $332 \mathrm{KK}$ dan rumah tangga miskin sebanyak $148 \mathrm{KK}$. Persebaran penduduk pada setiap dusun hampir merata, dimana penduduk paling banyak berada di Dusun Krajan sebanyak 2.548 jiwa (42,17\%) (BPS, 2019). Desa Sumberbening memiliki banyak organisasi masyarakat yang berfungsi untuk menunjang keharmonisan dan kesejahteraan penduduk. Desa Sumberbening berusaha untuk menjadi desa yang sehat, untuk itu diperlukan sarana kesehatan yang diharapkan bisa mendukung upaya tersebut sehingga Desa Sumberbening berhasil menjadi desa sehat.

Desa Sumberbening merupakan salah satu desa yang berada di wilayah jalur lintas selatan (JLS) yang termasuk dalam daerah di ujung Kota Malang. Jarak antara Desa Sumberbening dengan ibu kota kabupaten kurang lebih $55 \mathrm{~km}$ dan dapat ditempuh selama kurang lebih 1,5-2 jam perjalanan dengan menggunakan jalur darat. Lokasi desa yang jauh tersebut menjadikan suatu permasalahan, salah satunya ialah dalam akses pencarian sarana kesehatan yang memadai.

Kondisi lokasi beberapa dusun yang cukup jauh dengan fasilitas kesehatan yang memadai tidak menjadi satu-satunya permasalahan yang ada di Desa Sumberbening. Desa Sumberbening memiliki penduduk yang cukup simpati dengan sistem pertahanan kesehatan. Namun, interaksi nya dengan tenaga kesehatan masih belum cukup maksimal. Hal tersebut juga menjadikan kendala tersendiri dalam meningkatkan kesejahteraan kesehatan masyarakat di Desa Sumberbening.

Salah satu karakteristik lainnya yang ditemukan di Desa Sumberbening adalah masih banyak penduduk yang merupakan kategori penduduk hampir miskin dan miskin. Kemiskinan memiliki lima dimensi yang terdiri dari kemiskinan itu sendiri, ketidakberdayaan, kerentanan menghadapi situasi darurat, ketergantungan, dan keterasingan (baik geografis maupun sosiologis). Keadaan ekonomi yang rendah menjadi salah satu indikator dalam rendahnya pengetahuan masyarakat.

Berdasarkan hasil pengkajian dengan petugas Puskesmas Desa didapatkan hasil jika hipertensi merupakan salah satu masalah kesehatan paling tinggi di di Desa Sumberbening. Hipertensi merupakan silent killer yang apabila tidak dikontrol dengan baik dapat menyebabkan situasi emergensi seperti kegawatan jantung dan neurologis. Kondisi kegawatan jantung seperti serangan jantung dan neurologis seperti serangan stroke (CVA) merupakan salah satu penyebab kematian tertinggi di dunia. Ancaman yang cukup berbahaya dari kondisi tersebut memerlukan tindak lanjut yang cukup serius oleh seluruh orang, termasuk di Desa Sumberbening.

Peningkatan kejadian kondisi kegawatan jantung dan neurologis berhubungan dengan faktor dan penyakit berisiko yang disebabkan karena pola hidup yang kurang baik (Trisnowati, 2018). Hipertensi, penyakit jantung, dan diabetes melitus merupakan contoh dari penyakit berisiko yang dapat menimbulkan kondisi kegawatan jantung dan neurologis. Berdasarkan data Kemenkes (2013), penyakit-penyakit berisiko 
tersebut memiliki prevalensi sebesar $25,8 \%$.

Besarnya potensi kejadian gawat darurat / kondisi kegawatan harus diimbangi dengan peningkatan pengetahuan masyarakat dalam penanggulangan kejadian gawat darurat (Holly et al., 2017). Pengetahuan merupakan dasar dari suatu keterampilan dalam melakukan suatu hal. Pengetahuan masyarakat dapat ditingkatkan melalui kegiatan program kemitraan masyarakat dengan cara promosi kesehatan. Strategi promosi kesehatan yang baik ialah yang dapat memberdayakan masyarakat untuk dapat berpartisipasi dan memberikan pengaruh pada perubahan perilaku untuk mempertahankan derajat kesehatan (Dewi, 2013).

Upaya-upaya dalam meningkatkan ketahanan kesehatan diperlukan untuk dapat mencegah risiko kondisi-kondisi penyakit tertentu yang dapat membahayakan jiwa. Upaya pemberian informasi dengan cara memberikan pengenalan mengenai faktor dan penyakit berisiko yang dapat menimbulkan kondisi kegawatan perlu dilakukan. Berdasarkan pemaparan di atas terkait masalah yang ada di Desa Sumberbening, maka hal tersebut yang melatarbelakangi diadakannya kegiatan program kemitraan masyarakat ini. Kegiatan ini akan memberikan pengetahuan dan keterampilan dasar bagi kader kesehatan dan tim penggerak PKK untuk dapat melakukan deteksi dini kondisi kegawatan jantung dan neurologis.

\section{METODE}

Kegiatan Program Kemitraan Masyarakat di Desa Sumberbening, Kecamatan Bantur, Kabupaten Malang dilaksanakan dengan pendekatan peningkatan pemahaman dari para kader kesehatan dan tim penggerak Pembinaan Kesejahteraan Keluarga
(PKK) mengenai kondisi kegawatan jantung dan neurologis.

\section{ALAT DAN BAHAN}

Alat dan bahan yang digunakan selama proses kegiatan program kemitraan masyarakat (PKM) ini ialah LCD, layar proyektor, dan poster. Poster yang digunakan terdiri dari 3 jenis poster, yaitu poster faktor risiko kondisi kegawatan jantung dan neurologis, poster deteksi dini serangan jantung, dan poster deteksi dini serangan stroke. Poster digunakan untuk memudahkan proses pelatihan deteksi dini secara berkelompok. Pada akhir kegiatan PKM, poster akan diserahkan pada kader kesehatan untuk dapat disosialisasikan kepada seluruh masyarakat Desa Sumberbening.

\section{METODE PELAKSANAAN}

Metode pelaksanaan kegiatan dibagi menjadi tiga tahap, yaitu persiapan, pelaksanaan, dan evaluasi. Tahapan persiapan meliputi pendekatan kepada tokoh masyarakat dan petugas kesehatan untuk memohon izin terkait penyelenggaraan kegiatan PKM. Selain itu, pada tahap persiapan dilakukan diskusi dengan mitra untuk merumuskan permasalahan yang ada di lingkungan mitra dan solusinya yang ditempuh dengan kegiatan PKM ini. Tahap pelaksanaan meliputi kegiatan penyuluhan, pendidikan kesehatan, dan pelatihan deteksi dini kondisi kegawatan jantung dan neurologis. Tahap evaluasi pada peserta kegiatan dilakukan melalui observasi, pre-test dan post-test secara lisan, dan wawancara. Evaluasi dilakukan untuk mengukur pemahaman kader dan tim penggerak PKK terkait materi yang telah diberikan. Program ini dilakukan dengan tahapan-tahapan tersebut yang dapat berdampak pada keaktifan kader kesehatan dan tim penggerak PKK untuk meningkatkan derajat kesehatan 
masyarakat, khususnya pada masyarakat berisiko.

\section{HASIL DAN PEMBAHASAN}

Hasil kegiatan dari PKM yang berjudul "Upaya Pencegahan Kondisi
Kegawatan Jantung dan Neurologis pada Kader Kesehatan di Desa Sumberbening, Kecamatan Bantur, Kabupaten Malang dipaparkan dalam tabel 1 .

\section{Tabel 1. Hasil kegiatan PKM}

\begin{tabular}{|c|c|c|c|}
\hline No & Waktu & Kegiatan & Peserta \\
\hline 1 & 18 Januari 2020 & $\begin{array}{l}\text { Focus group discussion 1: } \\
\text { 1. Faktor-faktor yang berkontribusi pada } \\
\text { kondisi kegawatan jantung dan neurologis } \\
\text { 2. Penyakit yang berisiko mengalami kondisi } \\
\text { kegawatan jantung dan neurologis }\end{array}$ & 37 Kader \\
\hline 2 & 1 Februari 2020 & $\begin{array}{l}\text { Pelatihan kader: } \\
\text { Deteksi dini kondisi kegawatan neurologis } \\
\text { (stroke) dan kegawatan jantung (serangan } \\
\text { jantung) }\end{array}$ & 37 Kader \\
\hline 3 & 15 Februari 2020 & $\begin{array}{l}\text { Focus group discussion 2: } \\
\text { 1. Faktor-faktor yang berkontribusi pada } \\
\text { kondisi kegawatan jantung dan neurologis } \\
\text { 2. Penyakit yang berisiko mengalami kondisi } \\
\text { kegawatan jantung dan neurologis }\end{array}$ & $\begin{array}{l}19 \text { kader dan tim } \\
\text { penggerak PKK }\end{array}$ \\
\hline 4 & 29 Februari 2020 & $\begin{array}{l}\text { Pelatihan kader dan tim penggerak PKK: } \\
\text { Deteksi dini kondisi kegawatan neurologis } \\
\text { (stroke) dan kegawatan jantung (serangan } \\
\text { jantung) }\end{array}$ & $\begin{array}{l}19 \text { kader dan tim } \\
\text { penggerak PKK }\end{array}$ \\
\hline
\end{tabular}

Program Kemitraan Masyarakat pada pertemuan pertama setelah sebelumnya mengajukan izin pada Kepala Desa ialah pendidikan kesehatan mengenai faktor risiko dan penyakit yang berpotensi untuk kejadian kegawatan jantung dan neurologis. Pada pertemuan pertama, peserta yang hadir ialah 37 orang kader kesehatan. Sebelum memulai penyampaian materi, fasilitator melakukan tanya jawab untuk mengukur pemahaman peserta. Begitu pula setelah sesi pendidikan kesehatan selesai, fasilitator melakukan review kembali untuk mengevaluasi pemahaman peserta terkait materi yang disampaikan. Hasil evaluasi yang didapat ialah sebagian peserta mengalami peningkatan pemahaman setelah diberikan materi pendidikan kesehatan. Peserta yang hadir aktif dalam proses diskusi selama kegiatan PKM dilaksanakan.

Program Kemitraan Masyarakat pada pertemuan kedua ialah pelatihan terkait deteksi dini tanda-tanda kondisi kegawatan neurologis (stroke) dan kegawatan jantung (serangan jantung). Pada pertemuan kedua, peserta yang hadir ialah 37 orang kader kesehatan. Sebelum memulai penyampaian materi, fasilitator melakukan tanya jawab untuk mengukur pemahaman peserta. Begitu pula setelah sesi pelatihan selesai, fasilitator melakukan review kembali untuk mengevaluasi pemahaman dan kemampuan peserta terkait pelatihan yang disampaikan melalui redemonstrasi cara deteksi dini stroke dan serangan jantung. Hasil evaluasi 
yang didapat ialah sebagian peserta mengalami peningkatan kemampuan setelah diberikan pelatihan. Peserta yang hadir menunjukkan antusiasme dalam proses diskusi selama kegiatan PKM dilaksanakan.

Program Kemitraan Masyarakat pada pertemuan ketiga ialah pendidikan kesehatan mengenai faktor risiko dan penyakit yang berpotensi untuk kejadian kegawatan jantung dan neurologis. Pada pertemuan ketiga, peserta yang hadir ialah 19 orang kader kesehatan dan tim penggerak PKK. Sebelum memulai penyampaian materi, fasilitator melakukan tanya jawab untuk mengukur pemahaman peserta. Begitu pula setelah sesi pendidikan kesehatan selesai, fasilitator melakukan review kembali untuk mengevaluasi pemahaman peserta terkait materi yang disampaikan. Hasil evaluasi yang didapat ialah sebagian peserta mengalami peningkatan pemahaman setelah diberikan materi pendidikan kesehatan. Peserta yang hadir mengikuti kegiatan dengan tenang dan kooperatif selama kegiatan PKM dilaksanakan.

Program Kemitraan Masyarakat pada pertemuan keempat ialah pelatihan terkait deteksi dini tanda-tanda kondisi kegawatan neurologis (stroke) dan kegawatan jantung (serangan jantung). Pada pertemuan kedua, peserta yang hadir ialah 19 orang kader kesehatan dan tim penggerak PKK. Sebelum memulai penyampaian materi, fasilitator melakukan tanya jawab untuk mengukur pemahaman peserta. Begitu pula setelah sesi pelatihan selesai, fasilitator melakukan review kembali untuk mengevaluasi pemahaman dan kemampuan peserta terkait pelatihan yang disampaikan melalui redemonstrasi cara deteksi dini stroke dan serangan jantung. Hasil evaluasi yang didapat ialah sebagian peserta mengalami peningkatan kemampuan setelah diberikan pelatihan. Beberapa peserta datang terlambat, namun hal tersebut tidak begitu berpengaruh dengan kegiatan pelatihan yang dilaksanakan pada hari tersebut.

Program Kemitraan Masyarakat (PKM) telah terlaksana dan mengacu sesuai pada rencana kegiatan yang telah disusun. Evaluasi secara umum dari kegiatan PKM ini ialah terlaksanan kegiatan sesuai dengan jadwal yang telah ditetapkan, partisipasi kehadiran peserta pada saat kegiatan berlangsung, terdistribusikan nya poster deteksi dini kegawatan jantung dan neurologis kepada wilayah Desa Sumberbening.

Evaluasi lainnya ialah yang dilaksanakan terhadap para kader kesehatan dan tim penggerak PKK yang mengikuti kegiatan pengembangan kemampuan masyarakat. Evaluasi ini meliputi pengetahuan peserta yang terlibat dalam mengenali faktor dan penyakit berisiko yang memberikan potensi terjadinya kondisi kegawatan jantung dan neurologis. Evaluasi kepada masyarakat khususnya pada peserta yang terlibat dilakukan dengan cara melihat kemampuan peserta dalam melaksanakan deteksi dini kondisi kegawatan jantung dan neurologis serta antusiasme peserta dalam mengikuti kegiatan. Hasil evaluasi menunjukkan jika pemahaman peserta meningkat terkait kondisi kegawatan jantung dan neurologis. Hal tersebut perlu rencana tindak lanjut untuk mempertahankan pemahaman dan kemampuan para kader kesehatan dan tim penggerak PKK.

Kegiatan PKM ini telah terlaksana dengan baik yang telah didukung melalui keterlibatan para kader kesehatan dan tim penggerak PKK. Peran tenaga kesehatan dalam kegiatan ini masih sebatas pada proses pengkajian awal. Setelah dilaksanakannya kegiatan ini, tenaga kesehatan di wilayah PKM diharapkan untuk selanjutnya dapat menindaklanjuti kegiatan PKM yang telah dilaksanakan. Hasil kajian data yang telah didapat pada saat kegiatan 
PKM diharapkan dapat menjadi bekal untuk melanjutkan PKM dan programprogram yang sebelumnya telah ada dan berlangsung di Desa Sumberbening yang berkaitan dengan faktor-faktor penyebab dan deteksi dini kondisi kegawatan jantung dan neurologis. Dengan adanya program PKM ini, diharapkan tenaga kesehatan dapat meningkatkan keterlibatan masyarakat melalui program-program pemberdayaan masyarakat yang berkaitan dengan kegawatan jantung dan neurologis, sehingga dapat membantu menurunkan kejadian kegawatan jantung dan neurologi melalui deteksi dini.

Kader kesehatan merupakan salah satu target utama dalam kegiatan PKM ini. Dengan adanya kegiatan ini, diharapkan kader dapat meningkatkan kemampuan serta pemahaman terkait kondisi kegawatan jantung dan neurologi. Selain itu diharapkan kader kesehatan dapat melakukan sosialisasi kepada masyarakat sekitar setelah mendapatkan pelatihan dan pendidikan kesehatan dalam program ini. Hal tersebut diharapkan dapat memaksimalkan fungsi kader kesehatan sebagaimana mestinya dan dapat membantu mengubah pola pikir dan pola hidup masyarakat untuk meminimalkan terjadinya kegawatan jantung dan neurologis.

Tim penggerak PKK ialah target utama kedua setelah kader kesehatan. Harapan serupa juga diberikan pada tim penggerak PKK untuk dapat meningkatkan derajat kesehatan dan kesejahteraan jasmani masyarakat di Desa Sumberbening melalui penyegaran pemahaman terkait kondisi kegawatan jantung dan neurologis.

Program PKM ini pada akhirnya diharapkan dapat membantu meningkatkan derajat kesehatan masyarakat melalui perwakilan tokoh masyarakat, kader, dan tim PKK. Perwakilan masyarakat tersebut selanjutnya diharapkan untuk dapat menyebarkan informasi yang telah didapatkan selama mengikuti kegiatan PKM kepada masyarakat luas untuk menjaga kontinuitas program dan program dapat tercapai sesuai target. Kegiatan ini selanjutnya diharapkan dapat membantu masyarakat dalam meningkatkan pemahaman terkait dengan kondisi kegawatan jantung dan neurologis.

\section{KESIMPULAN}

Program Kemitraan Masyarakat (PKM) dengan judul PKM Kelompok Kader Kesehatan dan Tim Penggerak PKK Desa dalam Upaya Pencegahan Kegawatan Jantung dan Neurologis di Desa Sumberbening Kecamatan Bantur Kabupaten Malang telah terlaksana dengan baik. Kegiatan PKM tersebut mendapat sambutan baik dari masyarakat. Kegiatan PKM telah menjawab permasalahan yang ada di Desa Sumberbening mengenai banyaknya masyarakat yang memiliki penyakit dengan risiko mengalami kondisi kegawatan jantung dan neurologis. Kader kesehatan sebagai sasaran kegiatan PKM untuk selanjutnya telah berkomitmen untuk membagikan informasi yang telah didapat melalui kegiatan PKM kepada masyarakat sekitar lainnya. Hal tersebut terbukti juga dari partisipasi aktif kader terhadap kegiatan PKM yang dilaksanakan. Saran untuk kegiatan PKM selanjutnya ialah menambahkan topik mengenai cara penanganan awal jika terjadi kondisi kegawatan jantung dan neurologis pada seorang individu.

\section{DAFTAR PUSTAKA}

BPS. (2019). Kota Malang dalam angka (pp. 344). Malang: Badan Pusat Statistik Kota Malang. 
Dewi, F. S. T. (2013). Working with community: Exploring community empowerment to support non-communicable disease prevention in a middleincome country. (Doctor Disertation), Umea University.

Holly, D., Swanson, V., Cachia, P., Beasant, B., \& Laird, C. (2017). Development of a behaviour rating system for rural/remote pre-hospital settings. Applied
Ergonomics, 58, 405-413.

Kemenkes. (2013). Riset kesehatan dasar RISKESDAS. Jakarta: Balitbang.

Trisnowati. (2018). Pemberdayaan masyarakat untuk pencegahan faktor risiko penyakit tidak menular (Studi pada pedesaan di Yogyakarta). Jurnal MKMI, 14(1), 17-25. 